\title{
Unlocking wise digital techno- futures: Contributions from the Degrowth community
}

\section{Journal Article}

Author(s):

Pansera, Mario; Ehlers, Melf-Hinrich (10; Kerschner, Christian

Publication date:

2019-12

Permanent link:

https://doi.org/10.3929/ethz-b-000371476

Rights / license:

Creative Commons Attribution-NonCommercial-NoDerivatives 4.0 International

Originally published in:

Futures 114, https://doi.org/10.1016/j.futures.2019.102474 
Postprint

This is the accepted version of a paper published in Futures. This paper has been peer-reviewed but does not include the final publisher proof-corrections or journal pagination.

\section{Citation for the original published paper:}

Pansera, Mario, Melf-Hinrich Ehlers, and Christian Kerschner. 2019. 'Unlocking Wise Digital TechnoFutures: Contributions from the Degrowth Community'. Futures 114: 102474.

Access to the published version may require subscription.

N.B. When citing this work, cite the original published paper. 


\title{
Unlocking wise digital techno-futures: contributions from the Degrowth community
}

\author{
Mario Pansera \\ University of Bristol \\ Department of Management \\ Priory Road Complex \\ Priory Rd, Bristol \\ BS8 1TU, U.K. \\ mario.pansera@bristol.ac.uk
}

\section{Melf-Hinrich Ehlers}

ETH Zürich, Agricultural Economics and Policy Group

Sonneggstrasse 33, 8092 Zürich, Switzerland

+41446338860

mhehlers@ethz.ch

\section{Christian Kerschner}

Department of Sustainability, Governance, and Methods, MODUL University Vienna, Am Kahlenberg 1, 1190 Vienna, Austria

Department of Environmental Studies, Masaryk University.

Jostova 10, 602 00, Brno, Czech Republic

christian.kerschner@modul.ac.at

\begin{abstract}
Many of the great expectations of technology in the 1960s remain unfulfilled today. Alongside the optimism that drove technological development, sceptical views on the promises of technology have become popular and senses of deception, reflection, even hostility, emerged within Western societies. One such group is the Degrowth community, a heterogenous group of researchers and activists, who question technological advancements that contributed to environmentally and socially harmful economic growth. It critically observes current hypes of digital technology, which seem to follow a mantra of "the more
\end{abstract}


digital technology, the better". This paper presents perspectives that emerged from a dialogue among members of the Degrowth community, who were asked to imagine wise and unwise futures of digitalisation in 2068. Key concerns of unwise futures include increasing disconnection of humans from the natural environment and from one another as individuals, the use of digital technology for optimising the allocation of scarce resources to the benefit of the wealthy few and authoritarian governance of technologies and life itself. Wise technological futures, in turn, allow people to freely access digital technologies that are convivial, just, environmentally sustainable and guided by democratic deliberation. It remains controversial how far digital technologies and the interests and skills surrounding them can facilitate the principles of Degrowth and to what extent harmful effects of such technologies are already shaping social, ecological and technological futures. However, the dialogue clearly emphasised the need to develop more detailed socio-technological imaginaries that provide practically feasible alternatives.

\section{Where are all the flying cars?}

When the first issue of Futures appeared in 1968, people's collective imaginary in the industrialised countries envisioned a prosperous beginning of the twenty first century populated by flying cars and interplanetary travels. A sixties audience, though, would not be impressed by today's technological advancements. As the anthropologist David Graeber (2012) says "they thought we'd be doing this kind of thing by now. Not just figuring out more sophisticated ways to simulate it." Most of the last 50 years' technological advances, Graeber claims, were in simulation technologies based on information and communication technology (ICT). However, these technologies, if measured in terms of their contributions to total factor productivity, led to minimal and short-lived improvements compared to previous less glamorous technologies such as indoor plumbing or electricity (Gordon 2017). Total factor productivity increase has now fallen to pre-industrial levels - among other reasons - because ICT developments consume extra human time rather than saving it (see Bonaiuti 2018).

Even though ICT continues to dominate imaginaries of our technological futures, in Graeber's view there is also a sensation that repetition pervades our times. The feeling that nothing of what we see today is genuinely new and promising is also testified by a fading momentum of grand historical narratives of progress and liberation that characterised most 
of the last century (Coenen \& Grunwald, 2017; Gonzalez-Polledo \& Gonzalez-Polledo, 2018; McClure, 2018; Wakefield, 2018). Why, thus, did scientists, engineers, politicians and entrepreneurs fail to deliver a technological future that seemed just about to happen in the sixties, seventies and even eighties? Graeber contends that competition with the Soviets in the cold war fostered the progressive attitude of post-WWII capitalism. A new period of capitalist expansion accompanied the collapse of real socialism, just as Fukuyama (1992) declared that the fall of Soviet regimes represented the end of history and the beginning of a stable age in which capitalism would globalise peace and prosperity. However, it has failed to deliver the fabulous technologies that people dreamt of in the 1960s. Twenty-five years later, climate change, economic stagnation, rising inequality technological disasters like Fukushima, political instability and polarization between left and right become the new normal across the globe (Hickel, 2018). Streeck (2016) notes, that while capitalism is now obviously going through a drastic transformation, we are unable to imagine what will come afterwards.

Today global capitalism is stagnating amidst decreasing quality and quantity of our resource base (Kerschner \& Capellán-Pérez, 2017) and investments in technology are delivering ever diminishing returns (Bonaiuti, 2018; Gordon, 2017). Meanwhile, we seem to be distracted by tinkering with fabulous 3D movies and videogames or are busy to virtualize inter-human relationships via social media. Currently prevailing governance of economies seems to aim at efficiently squeezing the most out of the status quo that is shared by ever fewer individuals, including treasure hunts for the remaining untapped natural resources (Scheidel \& Sorman, 2012). At the same time, it fails to facilitate the development of imaginaries of viable futures and the creation of new value (see Mazzucato 2018). Strand et al. (2018) argue that the dominant narratives of innovation are all about increasing, or restarting, economic growth and culminate in a linear master narrative of innovation for growth ${ }^{1}$. The only mainstream innovation to the traditional "growth-focused" narrative has been the addition of hopes for "techno-science" to deliver sustainable or "green" growth. Hence, growth-fetishism is omnipresent in mainstream imaginaries of innovation and technology, despite years of accumulating evidence that economic growth is not a good universal

\footnotetext{
${ }^{1}$ Investment in science yields technological innovation, which delivers economic growth, which in turn leads to job creation, welfare and prosperity including technological solutions to environmental problems (Kerschner et al., 2018).
} 
indicator for human wellbeing, in particular as less and less people are benefiting from this growth (Hickel, 2018; Hickel \& Kallis, 2019; Piketty, 2014).

How can we re-imagine the organising principles of our societies to unlock technological futures that are viable alternatives to degrading society and ecosystems? When would corresponding futures be feasible and who will benefit? Today there is particularly great hope in digital technologies. However, a clear imaginary for a digital future is missing and the soaring digitalisation of virtually all aspects of our lives needs to be criticised (Zuboff, 2019). Pueyo (2018) for instance points at the dangers of using artificial intelligence for business management and Margetts and Dorobantu (2019) warn that it can misdirect policy. These fears and hopes are currently being discussed not only in science and technology studies, but also in various other research communities (Loader \& Mercea, 2011; Norris, 2001; Ziewitz, 2016). The Degrowth community that ponders about a future without ecologically destructive capitalist growth increasingly engages with such questions.

A recent special issue on the role of technology in a Degrowth society (Kerschner et.al. 2018) identified digitalisation as one of the areas in urgent need for further research, because of its ambiguous potential. In what follows, we present the perspectives on digitalisation that emerged from a dialogue among members of the Degrowth community that took place at the 6th International Degrowth Conference in Malmö in the August of 2018. The participants were asked to imagine and reflect upon wise and unwise futures of digital technology in 2068. Wis, the old English word from which "wise" and wisdom derive, refers to capability of being prudent, discreet, experienced, having the power of discerning and judging rightly. So, the participants had to imagine and evaluate digital futures with reference to these attributes.

\section{Degrowth as a provocative slogan for rethinking the future}

Over the past 50 years, communities of researchers, intellectuals, activists and artists have tried to develop and implement alternative imaginaries to the undesired social and environmental effects of industrial progress. One such community that recently gained much attention is the Degrowth community. It critically discusses and, in some cases develops, imaginaries that address issues of economic growth, environmental degradation and social disintegration (D’Alisa, Demaria, \& Kallis, 2014; Kallis, 2018; Kerschner, 2010). Although the community does not share an universal definition (Demaria, Schneider, 
Sekulova, \& Martinez-Alier, 2013; Kerschner et al., 2018), Degrowth is generally seen as 'a collective and deliberative process aimed at the equitable downscaling of the overall capacity to produce and consume and the role of markets and commercial exchanges as a central organizing principle of human lives' (Sekulova, Kallis, Rodríguez-Labajos, \& Schneider, 2013). Nevertheless, the Degrowth community does share much of Graeber's (2012) concerns about the diminishing (marginal) return of technological advances - e.g. see (Bonaiuti, 2018) - and about the possibility for capitalist elites to charge the costs of this stagnation to the vast majority of an impoverished population (Streek 2016). In addition, the Degrowth community assumes that the technological development that propelled economic growth in the last two centuries is no longer socially and environmentally sustainable and desirable (Jackson, 2009; Kallis, Kerschner, \& Martinez-Alier, 2012). In a nutshell, the Degrowth community challenges socio-technological imaginaries like those symbolised by flying cars on the basis of real needs for a 'good life', the wider social, ecological and personal benefits of simple life-styles and biophysical limits or resources in sinks (i.e. the capacity of ecosystems to absorb the waste-products of human activity such as CO2).

In this contribution, we explore socio-technical imaginaries of digitalisation for the next 50 years through a dialogue among a diverse group of academics and practitioners that participated in a workshop organised by the authors at the 6th International Degrowth Conference $^{2}$ for ecological sustainability and social equity held in Malmö, Sweden on 21-25 August 2018. The topic of the conference, "Dialogues in turbulent times", alludes to the uncertain times, full of insecurity and fear, we live in. However, we also witness a rise of new organising practices, small but numerous seeds for transformation in line with the principles of ecological sustainability, social justice and human flourishing as advocated by the Degrowth community (Bradley, 2018; Johanisova, Crabtree, \& Fraňková, 2013; Kostakis, Latoufis, Liarokapis, \& Bauwens, 2018; Pansera \& Owen, 2018).

The dialogue was open to all conference participants. A group of academics from different disciplines and practitioners, artists and Degrowth activists participated in the dialogue by self-selection, including researchers working on future studies. The dialogue lasted 90 minutes and was organised in three stages. First, the questions sketched out above were presented and briefly discussed. Then the 20 participants were split into three groups. Each

${ }^{2}$ https://malmo.degrowth.org - accessed on August 2018 
group reflected for one hour about the world they would like to live in 2068 and imagine what kind of world in 2068 they would fear. In particular, each group had to discuss the following questions:

- How do you imagine an unwise future in 2068? What organising principles will underpin our societies? What technological futures does this vision imply? What scale, what level of complexity? How do you think this will be achieved?

- How do you imagine a wise future in 2068? What organising principles will underpin our societies? What technological futures does this vision imply? How do you think this will be achieved?

The groups summarised their thoughts on flipcharts. The last stage consisted of a joint dialogue of desired and undesired futures that summarises the contributions from each group and stimulated reflection. This dialogue started off from presentations of the flipcharts. It was recorded digitally and analysed inductively according to the two opposing sets of questions. In the next section we are reconstructing the salient parts of the discussion in form of a dialogue between the participants and us organisers. We amended the material from the workshop based on additional reflections and references to fitting literature. The dialogue in the next section does not exactly mirror the patterns of communication in the workshop, as we also aimed to develop a coherent storyline. A first manuscript by the authors received comments online by the participants, which we took up for the final paper.

\section{Unwise futures: what members of the Degrowth community fear}

Organiser \#1:

"The Degrowth community is a heterogenous group of people who are united by a
radical critique of the presumed necessity for economic growth within modern societies.
However, I have the feeling that how "degrowth societies" should look like and what
steps need to be taken to build them is a matter of animated debate. We as a
community of scholars and activists have formulated a diversity of controversial
imaginaries of unwise technological futures. Our challenge in this dialogue is to identify
concepts that cut across such imaginaries. I refer to the notion of 'imaginary' not as
'science fiction' or 'fantasy' but, like Jasanoff and Kim (2009, p. 122) say, as a cultural 
resource that 'helps to produce systems of meaning that enable collective interpretations of social reality, ... the basis for a shared sense of belonging and attachment to a political community'. What kind of unwise future do we fear in the Degrowth community?"

\section{A participant:}

"I think what emerged in the group discussion is that people mainly fear 'disconnection'. Detachment from nature and people, this is what we fear. I feel that people in the Degrowth community are afraid of the level of disconnection from the rest of nature and from each other that human societies, mostly in the industrialised world, have reached. This is also embodied in the illusion of social interaction via virtual social relationships."

\section{Organiser \#2:}

"Actually, research in ecological economics, industrial and political ecology that underpins the Degrowth critique demonstrates the negative effects of this lack of connection for people and the environment as Kallis and colleagues (2010) suggest. I mean... look at what we teach in our universities... The fact that energy and material flows that feed human societies are largely unaccounted for in neoclassical economics and mainstream discourses catalysed the creation of imaginaries of an economy that is perpetually producing in an ecological vacuum, irrespective of natural boundaries."

\section{A participant:}

"Yes... but I'm more worried about a subtler form of disconnection that separates humans from nature... this is a dualism, a separation between humans and nature that objectifies the rest of the natural world, twists it, manages it, commodifies it and eventually destroys it. Plus... elites own digital technologies; we can't really control them, and this makes us uninfluential."

\section{Another participant:}

"In my discussion group we envisioned a future populated by disconnected and isolated individuals. This dystopic form of isolation was seen to result from erosion of the 
centrality of human agency vis-à-vis the rise of centralised ICT infrastructures. There is also this idea that all our relationships would be mediated through technology like today, but even worse: our friendships, our sexual lives, all things are mediated through tech, through virtual reality, because they prey on these very strong desires of us and will succeed in trapping us."

\section{Organiser \#3:}

"Interesting....so what we see here is a paradox... The increasing mediation of social life through ICT creates the paradox of a hyper interconnected world through the internet of things, big data, surveillance technologies, transparency of personal data etc., inhabited by otherwise socially disconnected individuals. I have attended a workshop on sustainability where one participant even argued in favour of an extreme scenario of a world in which people are trapped in a videogame life that prevents them from walking around and overconsuming natural resources - a sort of eco-fascist matrix. Similar extreme views can be implied in ecomodernism, as Grunwald (2018) suggests. He points at the manifesto of the Breakthrough Institute, who claim, apart from their support for nuclear power, that it is good for people to move and remain in the cities, in order to leave more space for nature."

\section{Organiser \#1:}

“... I think you are right. Digital technology can play a crucial role in controlling people's lives. ICT infrastructure might also be crucial to the politics of allocation of natural resources. Resource scarcity, aggravated by peak oil, climate change and environmental disasters might trigger new optimisation technologies that help allocating scarce resources ever more efficiently. As we presently address scarcity by investing in more efficient technological systems, it is likely that the future will be characterised by a desperate quest for efficiency improvements. Automated decision-making enabled by ICT could play a central role. The problem is that "efficiency" is predominantly defined as a maximisation of input-output ratios, in particular of money, ignoring social and environmental costs. Algorithms will be much more ruthless and effective in implementing this type of efficiency as a social ordering principle, an argument also made by Salvador Pueyo (2018) in the context of artificial intelligence." 


\section{Organiser \#2:}

"I think this is true... critics of our 'technological society' like Jaques Ellul (1964) have long warned about such dynamics. The perverse effect of this process is a depoliticization of social life in which social goods are allocated by algorithmic decisions instead of using deliberative democracy as Swyngedow (2015) warns. What do you think?

A participant:

"I think this is quite evident... automated decision-making (...) basically means that there is no decision-making. The mechanisms which are already in place and which are leading to global disaster will repeat and create knowledge and decisions which are more and more distant from the actual biophysical conditions as well as being distant from any desire of equity, because they are owned and driven in the interest of an elite."

\section{Organiser \#1:}

"I believe this is a very probable future scenario! I think we are already seeing similar mechanisms in place. These developments could also speed up the creation of marketbased authoritarian regimes. As we said in the introduction to this discussion mentioning Graeber's intuitions, investments in technology might be diverted towards the development of more efficient mechanisms to extract wealth for the wealthy few rather than designing flying cars or, even more importantly, new environmentally friendly technologies everyone can benefit from. Is this already happening with all the discourse about the austerity in the EU? My impression is that we already entered an era of zero-growth... in which digital technology, look at the case of financial markets, Uber or Airbnb, are used to capture and extract wealth from existing resources instead of creating it".

\section{A participant:}

\footnotetext{
"Maybe. What it is obvious is that an artificial scarcity can be constructed through regulating access to certain resources with unwise use of ICT. Artificial Intelligence (AI) technology, for instance, might increase inequality by establishing selective resource allocation mechanisms. Knowledge of algorithms, in the hands of few powerful actors,
} 
can increase inequality and have unpredictable consequences on human life. An example is the increasing complexity... and unpredictability of machine learning technology. We are creating piles of codes that are so complex that they can become totally unpredictable."

\section{Another participant:}

"I agree... what is scary is that we are living in a super connected world that is very fragile... in the future this fragility can undermine an equal distribution of the benefits of digital technologies. I think that we'll have a problem of access in the future. The scarcity of energy and materials that are essential to maintain network infrastructure and computing power is a serious problem. These limitations may jeopardize the broad accessibility of the internet as we know it today and exclude more and more individuals from information flows that are possibly vital for participating in certain societies. Some people will simply be thrown out of the internet because they cannot afford it, while the privileged few will maintain access. Consequently, the production of new imaginaries via the internet would be limited and controlled. ICT might favour a high-tech industrial complex with a strong power of manipulating people through the exclusive access to big data. Consider for example Chinese intentions for a social credit system. Who would want such a society in the first place? And can there be a stable society under such conditions? Probably not. Today, we already see an increasing concentration of power in the ICT industry, including Amazon, Apple, Facebook, Google and Microsoft."

\section{Organiser \#2:}

"It seems that some very relevant themes are emerging from this discussion. The first is the feeling and concern about disconnection. A sense of disaggregation of our bonds with our surrounding human communities but also with the environment that sustain us. The second theme is the concern about access and its implications in terms of equality, isn't it?"

\section{Organiser \#1:}

"I think so... these concerns are not only raised by our community... I think they are transversal themes common to others academic communities that, in some cases, are 
very diverse from each other. Even in the Degrowth community these issues are not universally understood and valued similarly. Just see the diversity in the special issue on Degrowth and technology edited by Kerschner and colleagues (2018) ..."

\section{The wisdom of conviviality: What members of the Degrowth community hope}

Organiser \#2

“... a characteristic of the degrowth community since the very beginning has been imagining not only different futures but also alternative ways of living the present. But what are these visions? What will wisdom look like in a world governed by Degrowth principles?

\section{Organiser \#3:}

"I think that we as a community have evolved a lot during the last 2 decades. Degrowth has been recently cross-pollinized with contributions from ecofeminism, anthropology and development studies as Kallis (2018) documented. The original focus on the ecological economics of our industrial society has gradually given room to a wider set of perspectives that include insights from the Global South, post-colonial and postdevelopment studies... It would be hard to put in one basket all the aspirations and perspectives about a wise future coming from all the people who in a way or another identify themselves with the critique that Degrowth puts forward."

\section{Organiser \#1:}

"I agree... I like the position of Arturo Escobar (2015b) when he states that Degrowth's critique should allow the flourishing of a pluriverse of ways of living, a variety of "alternatives to development", a multitude of diverse wisdoms, which question the hegemonic paradigm of globalised capitalism from different angles. All these perspectives fundamentally share an opposition to mainstream economics as the organising principle of society. The rise of neoliberalism, backed by the hegemony of neoclassical economics in the major universities and intellectual circles of the West, has slowly but steadily removed politics from the centre of organising our social life. 
Resources and social goods are supposed to be allocated according to the principles of economic efficiency. Colonising the imaginaries of many, mainstream economics acquired the status of an exact science with universal laws similar to the laws of physics. It was the economists' envy of the respect given to physicist that inspired them to create a theoretical construct based on classical mechanics as Spash (2011) argues. Only that physics has long moved away from Newtonian thinking, while neoclassical economics has barely moved at all. If social life can be scientifically organised according to a set of economic laws, politics, confrontation, debate and participation lose their meaning. Wisdom itself loses its original essence and Aristoteles's concept of phronesis no longer applies. Phronesis implies that socially right decisions are based on alliances of diverse social actors and always are context-dependent, contested, debated, political and unstable (Flyvbjerg, 2001). So, what about the capacity of digital technologies to enable a wise future? A future where 'right decisions' can be made?"

\section{A participant:}

"I think that many among us envision wise digital futures that - opposed to the universalistic logic of economics - are open to a multiplicity of ways of life. By default, this imaginary strongly opposes the implementation of automated decision-making that is an expression of economics as a natural science. Decision-making is always political. It might be eased by technology, but it should not be mediated or dominated by allegedly neutral technologies."

\section{Another participant:}

“... how to get out of it? The first step is to absolutely not let decision-making be directly or indirectly driven by big data and automated procedures in any way. Decision-making and organising of how we produce knowledge, the organising and thinking and purposing needs to be done through human communication and meetings and not mediated through automated systems, which does not mean that we cannot use technology. But it has to be used and not using us ..."

\section{Organiser \#3:}


"Well... I think that rather than dreaming of flying cars, most Degrowth scholars usually frame wise futures in terms of democratic, deliberative and responsible forms of governing technology. Although they refuse the rationality and alleged neutrality of dominant economic thinking, they do not necessarily oppose efficiency and productivity. Efficiency should be defined more broadly to include long and short term economic, social, political and environmental aspects and should be combined with regulation and social justice rather than being a goal per se. The pace of efficiency increases cannot be quick enough to make up for the decreasing quality and quantity of our resource base and the negative effects of climate change. On the contrary, rebound effects occur, which can temporarily accelerate the pace of resource consumption and increase inequality in resources allocation. If ill-guided, it will only make us more efficient in destroying our bases for existence."

\section{A participant:}

"[If efficiency was the solution] it would have happened two hundred years ago when we already started increasing productivity. The production of problems and potential disasters is going much quicker than the fixing through more efficiency. And increasing inequality has not been fixed by having more efficient technology, it's actually more aggravated."

\section{Organiser \#3:}

"This is true... actually the fixation on productivity gains can imply a paradoxical situation of uneconomic growth in which the disasters created by an endless maximization of material growth exceed its benefits. According to Illich (1973), modern societies - both capitalist and socialist - are locked into a race for technological development that generates environmental degradation and social disconnection. Instead of advancing the development of fabulous technologies, a wise future will be built upon a socio-technological imaginary that meets four main criteria: feasibility, viability, appropriateness and conviviality, to take the key criteria distilled by Kerschner et al. (2018). In the discussion groups, the concept that most participants seemed aware was Illich's formulation of 'conviviality'. Opposed to imaginaries of unwise futures characterised by disconnection, a "convivial future" according to Illich (1973) is based on 
the principle of connection and interdependence. I briefly quote his definition of conviviality:

'I consider conviviality to be individual freedom realized in personal interdependence and, as such, an intrinsic ethical value. I believe that, in any society, as conviviality is reduced below a certain level, no amount of industrial productivity can effectively satisfy the needs it creates among society's members.'" (Illich, 1973: 11)

\section{A participant:}

"But what does this imply for technology? What's a convivial technology?"

\section{Organiser \#3:}

“Vetter (2018) for example narrows down Illich's broad concept of convivial tools to define 'convivial technologies' with five core dimensions: relatedness, accessibility, adaptability, bio-interaction and appropriateness. In a wise future, technology has to create relatedness. One central message that is emerging in this discussion is that humans cannot live isolated existences. Instead they rely on a network of relationships. Technologies, especially ICTs, can enact and maintain these relationships, but not necessarily. Therefore, wise futures would imply technologies that universally allow an expansion of human relationships and capacities."

\section{Organiser \#1:}

"I would like to emphasise the accessibility of digital technology. Users have to be able to afford, understand and use, design, code and have to be provided with adequate documentation and shared standards. Accessibility also implies that disadvantaged communities can utilise, modify and adapt technology. This requires educated and empowered users, who can make informed decisions. Empowerment, in turn, implies the societal integration of technology as a choice not as a 'radical monopoly" sensu Illich (1973). Who can design, build or use it? Where, how, and for what purposes? These questions are rarely posed in conventional innovation projects."

\footnotetext{
3 The concept of radical monopoly introduced by Illich (1973) in his book "Tools for Conviviality" specifies those technologies that are unavoidable for people to be part of a given society. Today, highways, cars, computers and smartphones could be seen as such unavoidable tools in our society.
} 


\section{A participant:}

“... actually, you're touching a key point that the degrowth community shares with other movements like the open source movements or the commons movement. In a nutshell, wise futures would use technology that is easily reparable with simple tools, adaptable across different technological ranges and their environments and allow scalable levels of dependence. Examples are decentralised energy production infrastructures, a democratic and transparent organisation of the internet, open and distributed ICT platforms as opposed to the present enclosed platforms controlled by ICT industry giants."

\section{Another participant:}

"yes... but would adaptable technologies also allow people to remain the margins or to decide not to use a certain technology without being totally excluded from social life? These are technologies one can use but does not have to. A wise future would certainly involve 'techie' people but also the freedom to opt out - the liberty to be "a-tech" without being marginalised. It is important to have the option of being a non-digital citizen, I mean it sounds simple, but ..."

\section{A participant:}

"In practice what you suggest is that wise futures should allow the flourishing of appropriate and "wise" technologies ... appropriate or intermediate technology as those promoted by Schumacher (1973). I think this concept has similar attributes to conviviality, but it emphasises the values and aspirations of people, their context, local circumstances and cultural diversity. Efficiency and productivity must be balanced against the need for time for socially enriching activity."

\section{Another participant:}

"In this sense, I'd like to suggest to adopt the slogan "slow computing" or "lean computing" to symbolise a technological development that can harness enthusiasm, innovation and creativity at a human scale, slow enough to be reflective, corresponding to needs of people rather than serving the logic of technocratic centralisation in everaccelerating capitalism. Illich would have supported such an approach as he took issue 
with speed in other areas of human life, in particular transport. He famously proposed the reduction of all speeds of transport to that of a bicycle (Illich 1973)... to unlock our fantasies, I think that for a wise Degrowth future we will all gather under the banner of slow computing and we can discuss what that means ... would also be inclusive and equal by definition, because fast computing, only some can afford the fastest stuff ... Slow computing may also fit to Langdon Winner's concept of "methodological luddism", which was recently introduced to the Degrowth community by Garcia et al. (2018)."

\section{Organiser \#1:}

"I don't know... slow doesn't necessarily mean equal and just. I think a wise technological future should enable democratization of the use of technology. Nobody should be excluded from becoming 'technologically autonomous' because of low income, nationality, gender and abilities. This requires the facilitation of access to certain technologies ...in terms of know-how (open source); necessary skills for production (prosumers), use and repair; income (affordability) and gender. Initiatives that are inspired by this idea include: 'open-source design', 'prosumers', 'collaborative value creation', 'digital commons' and 'commons-based peer-to-peer production'. The attractiveness of such technological arrangements for me lies in the possibly flat hierarchies of such initiatives, their alleged potential to erode capitalist modes of production and in the hope that certain technologies catalyse the transformation into a convivial Degrowth society. The conviviality of the liberation of having to be at a certain time at a certain place are part of this approach.

\section{A participant:}

"I agree... and I want to say something optimistic [...] although we have not solved many problems with productivity and big factories, we also have seen in a lot of alternative projects that ICT has been used to create decentralized resource efficient solutions by using small computers and more adaptable devices. If we are able to put these technologies more in the hands of people and avoid their control via big corporate giants, we might have a different future for digitalization".

\section{Organiser \#2:}


"I can see the attractiveness of the 'technological democratisation' argument as described in the previously mentioned special issue by Kerschner et al. (2018). Proponents of technological democratization often refer to themselves as "optimists" and see efforts to constrain certain technologies like ICT as pessimism. And overall, I think people like optimistic messages. However, we shouldn't ignore that there is a tendency in such approaches to focus only on certain aspects of conviviality and appropriateness (e.g. ownership of production capacities) while completely ignoring biophysical considerations such as rebound effects and the 'feasibility' and 'viability' of such 'recipes' as defined by Georgescu-Roegen (1971, 1975). Feasible processes are those that can be reproduced within the desired time and conditions, given knowledge of its flow and fund coordinates ${ }^{4}$. 'Viable' on the other hand are only technologies which can maintain the material structure that supports their sink and resource functions indefinitely (or at least for geological times). Only then can they support human activity over the long run. For instance, although there was this person who circled around the world in a boat powered by his own body-fat it would be ill-conceived to assume that such experiments could make any viable contribution to our energy mix. Similarly, Gomiero (2018) argues that it may be feasible to convert all of Germany's agriculture to organic practices, but this may not be a viable option to sustain its current population."

\section{Organiser \#2:}

"Biophysical considerations in wise digital futures appeared to be more present in some groups in our dialogue than in others. A common start is the premise that biophysical constraints and limitations of the quality and quantity of our resource base constituted the foundations of any future imaginary, be it wise or unwise. This means no-one among us expected miracle technologies to produce energy or to save resources to appear at any time soon or at all. The Degrowth community is one that embraces limits as opportunities for change".

\section{A participant:}

\footnotetext{
4 “Georgescu-Roegen's (1971) distinction between flows (inputs, outputs and maintenance flows) and funds (capital equipment, Ricardian land and labour) is one of his most appreciated contributions (see Kerschner, 2010; Muraca \& Neuber, 2018), providing inspiration for today's work on societal metabolisms (e.g. Giampietro et al., 2011)" (Kerschner et al. 2018, p. 1628).
} 
"... you could very well have a multiplicity of people, of groups across the world living differently, exploring different paths, which we have to do anyway as we are going to run out (of fossil fuels) ..."

\section{Synthesis and final thoughts}

The participants of the presented dialogue were asked to imagine digital futures they fear and futures they hope for. This was not an easy task. The participants struggled to construct shared imaginaries of a future society and imagining themselves in those futures. This reflects very well the observation that the Degrowth community does not speak with one voice with respect to the aspired role of technology in a Degrowth society. Nevertheless, some themes clearly emerged from the dialogue. Apart from the concerns about biophysical limits to technology development, most members of the participants feared the conditions of disconnection and isolation that digital technology can create. This fear was clearly associated with a feeling that we as communities and individuals are losing control over the governance of technological development. Furthermore, in the dialogue there was generally more emphasis on unwise digital futures, which may relate to commonly critical engagements of Degrowth scholars and activists with society and technology where digitalisation increasingly pervades current practices and visions. The rejection of the dominant socio-technological narratives of "innovation for growth" was largely shared. However, perspectives on or 'attitudes towards technology' (see Kerschner and Ehlers 2016) in the Degrowth community consist of both enthusiasm and scepticism but to different degrees while also determinism and agency of technology are being considered. This fits the argument that a dogmatic approach would be against the very ethos of Degrowth and the suggestion that the maintenance and advancement of a critical and reflective dialogue between the different perspectives may be the best strategy (Kerschner et al. 2018).

Alike many other visionaries, the Degrowth community devotes much of its efforts in imagining alternative and possibly wise futures. These do not necessarily involve flying cars, but they do require a profound change in the way we frame technology and its role in our lives. This in turn requires reshaping production and changing the economic logic that propels growth. Furthermore, the dialogue was pervaded by the uncomfortable feeling that we are already living in unwise times. Outside the room, Sweden was being hit by an unprecedented drought and wildfires were raging in parts of the country. Such moments of 
crisis can certainly degenerate into chaos, which provides fertile ground for authoritative responses of the elites. But crisis can also open windows of opportunity and allow new imaginaries to emerge. Can there be a collection of futures in which different communities experiment different forms of convivial life? Are these isles, as Ezio Manzini (2015) suggests, the peaks of a submerged continent that is about to emerge from the ruins of the status quo? Or will the future be populated by isolated 'Degrowth isles' scattered in a generalised chaos?

The need to actively create visions and imaginaries of a future Degrowth Society, including the role of technology in such a society (Kerschner et al. 2018) inspired this dialogue on wise digital futures from Degrowth perspectives. Many questions remain unanswered. It is not clear whether the deliberative approaches that many of the Degrowth community advocate are feasible at a regional or global scale. Moreover, huge uncertainty surrounds the ways wise and unwise futures will be framed and governed in emergent global powers like China, Russia, India or emerging economies in Africa and Latin America. Whatever futures the next generation can expect, the Degrowth community hopes they will be plural and just.

\section{Acknowledgements}

We'd like to thank the organisers of the 6th International Degrowth Conference to provide the infrastructure to carry out the dialogue and to list the event in the conference programme. Christian Kerschner acknowledges funding received from the Czech science foundation under the project VE²NEX (GA CR 16-17978S)

\section{Participants of the dialogue}

Alan Borning, Ben Gallant, Christoph Wenzel, Daniel Pargman, Gualter Baptista, Helen Avery, Jamil Khan, Jeroen van Gorp, Jose Abad, Laura Colombo, Naomi Lipke, Pierre Smith Khanna, Roger Hildingsson, Simon Mair, Valentin Vogl, Verena van Zyl Bulitta, a person that preferred to stay anonymous.

\section{References}

Bonaiuti, M. (2018). Are we entering the age of involuntary degrowth? Promethean technologies and declining returns of innovation. Journal of Cleaner Production, 197, 1800-1809. https://doi.org/https://doi.org/10.1016/j.jclepro.2017.02.196 
Bradley, K. (2018). Bike Kitchens - Spaces for convivial tools. Journal of Cleaner Production, 197, 1676-1683. https://doi.org/https://doi.org/10.1016/j.jclepro.2016.09.208

Coenen, C., \& Grunwald, A. (2017). Responsible research and innovation (RRI) in quantum technology. Ethics and Information Technology, 19(4), 277-294. https://doi.org/10.1007/s10676-017-9432-6

D’Alisa, G., Demaria, F., \& Kallis, G. (Eds.). (2014). Degrowth: a vocabulary for a new era. New York and London.: Routledge.

Demaria, F., Schneider, F., Sekulova, F., \& Martinez-Alier, J. (2013). What is Degrowth? From an activist slogan to a social movement. Environmental Values, 22(2), 191-215. https://doi.org/10.3197/096327113X13581561725194

Ellul, J. (1964). The technological society. New York: Vintage.

Escobar, A. (2015). Transiciones: a space for research and design for transitions to the pluriverse. Design Philosophy Papers, 13(1), 13-23. https://doi.org/10.1080/14487136.2015.1085690

Flyvbjerg, B. (2001). Making social science matter. Cambridge, UK: Cambridge University Press.

Fukuyama, F. (1992). The end of history and the last man. London: Penguin Books Ltd.

Garcia, J. L., Jerónimo, H. M., \& Carvalho, T. M. (2018). Methodological Luddism: A concept for tying degrowth to the assessment and regulation of technologies. Journal of Cleaner Production, 197, 1647-1653. https://doi.org/https://doi.org/10.1016/j.jclepro.2017.03.184

Georgescu-Roegen, N. (1971). The entropy law and the economic process. Cambridge, Mass.: Harvard University Press.

Georgescu-Roegen, N. (1975). Energy and economic myths. Southern Economic Journal, 41(3), 347-381.

Gomiero, T. (2018). Agriculture and degrowth: State of the art and assessment of organic and biotech-based agriculture from a degrowth perspective. Journal of Cleaner Production, 197, 1823-1839. https://doi.org/https://doi.org/10.1016/j.jclepro.2017.03.237

Gonzalez-Polledo, E., \& Gonzalez-Polledo, E. (2018). Can digital health save democracy? Meeting the cosmopolitical challenge of digital worlds. Journal of Social and Political Psychology, 6(2), 631-643. https://doi.org/10.5964/jspp.v6i2.939 
Gordon, R. J. (2017). American growth: The U.S. standard of living since the Civil War. Princeton University Press.

Graeber, D. (2012). Of flying cars and the declining rate of profit. The Baffler No 19. Retrieved from https://thebaffler.com/salvos/of-flying-cars-and-the-declining-rate-ofprofit

Grunwald, A. (2018). Diverging pathways to overcoming the environmental crisis: A critique of eco-modernism from a technology assessment perspective. Journal of Cleaner Production, 197, 1854-1862. https://doi.org/10.1016/J.JCLEPRO.2016.07.212

Hickel, J. (2018). the divide: a brief guide to global inequality and its solutions. London: Penguin Random House.

Hickel, J., \& Kallis, G. (2019). Is green growth possible? New Political Economy, 1-18. https://doi.org/10.1080/13563467.2019.1598964

Illich, I. (1973). Tools for conviviality. New York: Harper \& Row.

Jackson, T. (2009). Prosperity without growth? The transition to a sustainable economy. Sustainable Development. London: Sustainable Development Commission.

Jasanoff, S., \& Kim, S.-H. (2009). Containing the atom: Sociotechnical imaginaries and nuclear power in the United States and South Korea. Minerva, 47(2), 119-146. https://doi.org/10.1007/s11024-009-9124-4

Johanisova, N., Crabtree, T., \& Fraňková, E. (2013). Social enterprises and non-market capitals: a path to degrowth? Journal of Cleaner Production, 38, 7-16. https://doi.org/10.1016/J.JCLEPRO.2012.01.004

Kallis, G. (2018). Degrowth. Newcastle upon Tyne: Agenda Publishing.

Kallis, G., Kerschner, C., \& Martinez-Alier, J. (2012). The economics of degrowth. Ecological Economics, 84, 172-180. https://doi.org/10.1016/j.ecolecon.2012.08.017

Kallis, G., Schneider, F., \& Martinez-Alier, J. (2010). Growth, Recession or Degrowth for Sustainability and Equity? (Special Issue). Journal of Cleaner Production, 18(6), 511606.

Kerschner, C. (2010). Economic de-growth vs. steady-state economy. Journal of Cleaner Production, 18(6), 544-551. https://doi.org/10.1016/J.JCLEPRO.2009.10.019

Kerschner, C., \& Ehlers, M.-H. (2016). A framework of attitudes towards technology in theory and practice. Ecological Economics, 126, 139-151. https://doi.org/10.1016/j.ecolecon.2016.02.010 
Kerschner, C., \& Capellán-Pérez, I. (2017). Peak-Oil and Ecological Economics. In C. L. Spash (Ed.), Routledge Handbook of Ecological Economics: Nature and Society. London: Routledge.

Kerschner, C., Wächter, P., Nierling, L., Ehlers, M.-H., Wächter, C. K. P., Nierling, L., \& Ehlers, M.-H. (2018). Degrowth and technology: Towards feasible, viable, appropriate and convivial imaginaries. Journal of Cleaner Production, 197, 1619-1636. https://doi.org/10.1016/J.JCLEPRO.2018.07.147

Kostakis, V., Latoufis, K., Liarokapis, M., \& Bauwens, M. (2018). The convergence of digital commons with local manufacturing from a degrowth perspective: Two illustrative cases. Journal of Cleaner Production, 197, 1684-1693. https://doi.org/https://doi.org/10.1016/j.jclepro.2016.09.077

Loader, B. D., \& Mercea, D. (2011). NETWORKING DEMOCRACY? Information, $\begin{array}{llll}\text { Communication } \quad \& \quad \text { Society, } & \text { 757(6), }\end{array}$ https://doi.org/10.1080/1369118X.2011.592648

Manzini, E. (2015). Design, when everybody designs: An introduction to design for social innovation. Cambridge, Mass.: MIT press.

Margetts, H., \& Dorobantu, C. (2019). Rethink government with Al. Nature, 568(7751), 163165. https://doi.org/10.1038/d41586-019-01099-5

Mazzucato, M. (2018). The Value of everything. London: Penguin Books.

McClure, P. K. (2018). "You're fired," says the Robot. Social Science Computer Review, 36(2), 139-156. https://doi.org/10.1177/0894439317698637

Muraca, B., \& Neuber, F. (2018). Viable and convivial technologies: Considerations on climate engineering from a degrowth perspective. Journal of Cleaner Production, 197, 1810-1822. https://doi.org/https://doi.org/10.1016/j.jclepro.2017.04.159

Norris, P. (2001). Digital divide : civic engagement, information poverty, and the Internet worldwide. Cambridge University Press. Retrieved from https://books.google.ch/books?hl=de\&lr=\&id=wfNPdyiwbYQC\&oi=fnd\&pg=PP11\&dq= digital+divide\&ots=gAgK8csUcP\&sig=wlqalH9sCFOCEOy__4_L9PMflk\#v=onepage \&q=digital divide\&f=false

Pansera, M., \& Owen, R. (2018). Innovation for de-growth: A case study of counterhegemonic practices from Kerala, India. Journal of Cleaner Production, 197(2), 1872- 
1883. https://doi.org/10.1016/j.jclepro.2016.06.197

Piketty, T. (2014). Capital in the twenty-first century. Cambridge, Mass.: Harvard University Press.

Pueyo, S. (2016). Growth, degrowth, and the challenge of artificial superintelligence. Journal of Cleaner Production, 197, 1731-1736. https://doi.org/10.1016/j.jclepro.2016.12.138

Scheidel, A., \& Sorman, A. H. (2012). Energy transitions and the global land rush: Ultimate drivers and persistent consequences. Global Environmental Change, 22(3), 588-595. https://doi.org/10.1016/J.GLOENVCHA.2011.12.005

Schumacher, E. F. (1973). Small is beautiful. New York: Harper \& Row.

Sekulova, F., Kallis, G., Rodríguez-Labajos, B., \& Schneider, F. (2013). Degrowth: from theory to practice. Journal of Cleaner Production, 38, 1-6. https://doi.org/10.1016/j.jclepro.2012.06.022

Spash, C. L. (2011). Social ecological economics: Understanding the past to see the future. American Journal of Economics and Sociology, 70(2), 340-375. https://doi.org/10.1111/j.1536-7150.2011.00777.x

Strand, R., Saltelli, A., Giampietro, M., Rommetveit, K., \& Funtowicz, S. (2018). New narratives for innovation. Journal of Cleaner Production, 197, 1849-1853. https://doi.org/10.1016/j.jclepro.2016.10.194

Streeck, W. (2016). How will capitalism end? London: Verso.

Swyngedouw, E. (2015). Depoliticization ('The Political'). In Giacomo D'Alisa, F. Demaria, \& G. Kallis (Eds.), Degrowth. A vocabulary for a new era. Oxon: Routledge.

Vetter, A. (2018). The Matrix of convivial technology - Assessing technologies for degrowth. Journal of Cleaner Production, 197, 1778-1786. https://doi.org/10.1016/J.JCLEPRO.2017.02.195

Wakefield, S. (2018). Infrastructures of liberal life: From modernity and progress to resilience and ruins. Geography Compass, 12(e12377). https://doi.org/10.1111/gec3.12377

Ziewitz, M. (2016). Governing algorithms. Science, Technology, \& Human Values, 41(1), 316. https://doi.org/10.1177/0162243915608948

Zuboff, S. (2019). The age of surveillance capitalism: the fight for a human future at the new frontier of power. London: Profile Books. 